\title{
SUBJECTIVELY AND OBJECTIVELY INTEGRATED ASSESSMENT OF THE QUALITY INDICES OF THE SUBURBAN RESIDENTIAL ENVIRONMENT
}

\author{
Dovilè LAZAUSKAITE் a,*, Marija BURINSKIENE் a, Valentinas PODVEZKO b \\ ${ }^{a}$ Department of Urban Engineering, Faculty of Environmental Engineering, Vilnius Gediminas Techni- \\ cal University, Sauletekio al. 11, LT-10223 Vilnius, Lithuania \\ ${ }^{b}$ Department of Mathematical Statistics, Faculty of Fundamental Sciences, Vilnius Gediminas Techni- \\ cal University, Sauletekio al. 11, LT-10223 Vilnius, Lithuania
}

Received 30 April 2014; accepted 29 April 2015

\begin{abstract}
The development of suburban residential areas influences the increasingly growing disparities between residential areas of a local municipal network. Real positive indicator values of settlements are usually used by planners to characterise the residential quality of a suburban settlement and to decide on its future development. These values frequently differ from choices made by urban residents on living under conditions of such interpretive suburban residential quality. It is the essence of spontaneous development in suburbs. This article aims to devise an integrated evaluation instrument that combines the objective and subjective evaluation of the quality indices of suburban residential environment. It introduces the following topics: (1) the identification of subjective and objective indices of the suburban residential environment; (2) development of the previous conceptual model of subjectively and objectively integrated quality indices used for the assessment of the suburban residential environment, and (3) comparison of suburban settlements by the existing conditions of the residential quality and the quality of the residential environment expected by potential residents. This piece of work is a part of a wider research.
\end{abstract}

KEYWORDS: Suburbs; Residential environment; Expert rating; Entropy weights; Priority sequence

\section{INTRODUCTION}

The outcome of urban-rural interaction in suburban territories depends on the functioning of the urban system and the scope of development (Collis et al. 2010). Problems arising in the urban system are taken over by adjacent rural territories (Phelps 2010; Ewing, Cervero 2010; Modarres, Kirby 2010; Forsyth 2012). The latter suffer more because of the significance of the city's impact. The article considers the aims of the investigation and focuses on the outcome of urban-rural interaction. In other words, it investigates the residential environment (natural and anthropogenic) of suburban and rural areas and its quality. It is the essence of spontaneous development in suburbs.

Researchers are encouraged to start an integrated assessment of the quality of the residential environment to satisfy the needs of all stakeholders comprehensively and collectively (Kaklauskas, Zavadskas 2009).

\footnotetext{
* Corresponding author. E-mail: dovile.lazauskaite@vgtu.lt
}

The main objective of this research is to compare selected indicators by two aspects: potential residents and urban planners. Real positive indicator values of settlements are usually used by planners to characterise the residential quality of a suburban settlement and to decide on its future development. The values frequently differ from choices made by urban residents on living under conditions of such interpretive suburban residential quality. It is the essence of spontaneous development in suburbs.

Consequently, it is important not to use a lot of indicators but to combine two important opinions. A method should be found for generalisation of the concept of the suburban residential quality. This method should be used for the purpose of rational planning. This article aims to devise an integrated evaluation instrument that combines the objective and subjective assessment of the quality indices of the residential environment. 
Scientific insights into the concept of quality and assessment methods of the suburban residential environment were used to establish the conceptual model of subjectively and objectively integrated assessment of the quality indices of the suburban residential environment. A reliable result should provide the sequence of integrally-based priority significances of suburban residential environment indices. The use of this integrated sequence in further research could help to compare suburban settlements by existing conditions of the residential quality and the quality of residential environment expected by potential residents. Such comparison of suburban settlements could be a significant tool for the control of suburban development.

Vilnius was used as a case to clarify the assessment model and to show a difference between objective and subjective assessment of residential quality. Also, the case was used to substantiate the importance of objective and subjective assessment of residential quality before using it in practice.

\section{INSIGHTS ON QUALITY OF THE SUBURBAN RESIDENTIAL ENVIRONMENT}

There is no clear definition of the residential environment in the scientific literature. The notion of the residential environment complies best with the notion of the built environment which was introduced 40 years ago in foreign scientific literature. The latter originated from anthropogenic and human behaviour studies, which aimed to explain the impact of the environment on the individual and social behaviour of people (Rapoport 1976). Later, the notion of the residential environment was defined as the result of the building process (Lawrence, Low 1990). Then it was specified as man-made surroundings that provide the setting for human activity, ranging in scale from personal shelter to neighbourhoods to the large-scale civic surroundings (Moffatt, Kohler 2008).

Lithuanian researchers regard the urban environment as a constituent of the entire urban system. The environment consists of natural and anthropogenic endogenous environment, where a majority of sustainable urban processes take place, and the exogenous environment, without which the existence of the city is practically impossible (Juškevičius, Burinskienè 2007). The residential environment is defined as a part of the total environmental system, which interacts through the relationship between the society, economic development and human intelligence (Burinskienè, Rudzkienè 2007). Such explanation of the notion of the environment in the system of urban territories enables us to compare notions of the residential environment and the urban environment. The latter is described by researchers as an integrated, social, cultural space connecting a relatively compact group of residents (Tupènaitè et al. 2010).

Such explanation of the notions and their comparison enables us to understand that both natural and artificial endogenous and exogenous types of the urban environment are the indispensable elements of the environment as a system. Besides, their quality impacts on the inhabitants and the city as well as residential areas within the city's zone of influence (suburbs).

The quality of the environment depends on various components of a specific sector. Each component (built environment, infrastructure, nature, and other facilities of the social, physical and economic environment) has a special characteristic and a value of quality. Most of the existing concepts in the field of residential environment quality are related to the quality of life concepts. They find their origin in the research of health, safety, well-being, residential satisfaction and urban physical environment (Van Kamp et al. 2003). Quality of life is often equated with well-being. It is amenable to both objective and subjective assessment and analysis (Helburn 1982; Beesley, Russwurm 1989; Felce 1997; Prutkin, Feinstein 2002; Gifford 2002; Bonaiuto 2004; Frey, Stutzer 2005). There is no complete agreement on what describes "good" quality of life. A good quality environment gives a sense of welfare and satisfaction to inhabitants by physical, social or symbolic characteristics (Marans, Couper 2000; Olsen, Merwin 1977). It has been observed that "what contributes to the quality of life of people is ultimately determined by them, and also that people's notion of quality of life is thoroughly infused with normative values concerning what is good and right in life".

Therefore, every study on the quality of life of any people should be based on their conception of good life. There are two main ways of conceptualizing quality of life: real conditions of life (objective) and experience of life (subjective).

Objective measures include using original existing data and expert judgements. They can be useful when validating subjective measures (Van Kamp et al. 2003). However, a considerable disagreement was detected between assessment of experts (e.g. planners) and individuals (Lansing, Marans 1969; Steg et al. 2007; Fawcett et al. 2008).

Experts (e.g. urban planners) tend to overestimate what is important to the general public 
of experts and underestimate the importance of individual resident factors (Perlavičiūtè, Steg 2012). Therefore, objective measurements alone do not provide a comprehensive understanding of how residents experience their environments and should be complemented by subjective measures (Marans 2003). Objective appraisals of the quality of life typically focus on levels of provision of basic human needs, such as housing, healthcare, education, community safety, and transportation (Dasgupta, Weale 1992).

Subjective measures are based on resident perceptions of their residential environments. This information can be acquired by asking participants to assess the quality characteristics of their neighbourhood (Amerigo, Aragones 1997; Van Poll 1997; Bonaiuto et al. 2006; Fornara et al. 2010). Based on the Van Poll's research, the quality of the residential environment is a subjective value concept. This value is defined by the value of "residential environmental quality" which contains such essential characteristics as individual resident's satisfaction with their house, neighbourhood and neighbours. Accordingly, the total subjective value of the quality of the residential environment is equal to the sum assessments of characteristics and components of the environment (Van Poll 1997). The residential quality perceived by residents defines residential well-being than merely objective indicators of neighbourhood conditions.

Environmental quality is an assessment of the environment in connection with one or more aspects, requirements or for any human need or desire (Johnson et al. 1997). Many researches were made in the field of assessment of the environmental quality (Amerigo, Aragones 1997; Adriaanse 2007; Erdogan et al. 2007; Vera-Toscano, Alteca-Amestoy 2008; James 2008). Some of these researches considered subjective aspects of quality and especially the satisfaction of residents, others studied objective aspects. Also, attempts have been made to combine objective and subjective aspects of the residential environment quality. However, no integrated system for the assessment of environmental quality in local areas was suggested.

Most of the existing approaches to the quality of the residential environment emphasise subjective and objective characteristics. Census data on objective variables are readily available in a spatially aggregated form. They can be combined in composite indices using various weighting schemes. The subjective evaluation of the quality of life is more difficult and expensive. It requires a questionnaire survey of individual respondents on their satisfac- tion with various aspects ('domains') of their life and their life in general (Andrews, Withey 1976; Chamberlain 1985; Diener, Lucas 2000).

\section{CONCEPTUAL MODEL OF SUBJECTIVELY AND OBJECTIVELY INTEGRATED ASSESSMENT OF THE QUALITY INDICES OF THE SUBURBAN RESIDENTIAL ENVIRONMENT}

Methods, which mostly support subjective or objective evaluation of quality in the field of urban planning, contain hierarchical multiple regression, multi-attribute utility, expert system (Kauko 2007), conjoint analysis (Van Poll 1997), confirmatory factor analysis (Costello, Osborne 2005; Kline 2005) and multi-criteria evaluation methods. Recently, multi-criteria evaluation methods have been widely employed in both theoretical investigation and solution of practical tasks (Saaty 1980; Hwang, Yoon 1981; Hwang, Lin 1987; Figueira et al. 2005; Podvezko, Podvezko 2010; Podvezko 2011; Ginevičius et al. 2012; Ginevičius, Podvezko 2013; Yazdani-Chamzini 2014). A multi-criteria evaluation method may be used to assess the structure of criteria values, i.e. the real dominant degree of each index. These will be objective weights of indices determined by the method of entropy, which enables to evaluate the real structure of an array of quality indices of the residential environment.

The conceptual model (Fig. 1) demonstrates how subjective and objective assessments could be combined and what results can be expected from this model.

Two aspects are considered in terms of the quality of the suburban residential environment: perceptions of potential residents and urban planners. Usually, urban planners evaluate the residential environment using extensive indicators that are based on existing data. Attempts have been made to combine these aspects.

The condition of the residential environment could be evaluated according to the principle of comparing numerical values of ten physical indices usually used by planners. Therefore, the real dominant degree of each index will be evaluated additionally, based on physical values of indices. It will be objective weights of indices.

The expert method could be used to analyse the selected indicators in the subjective way. The source of subjective evaluation data of the residential environment could be the opinion of potential residents of the suburban residential environment (experts). 


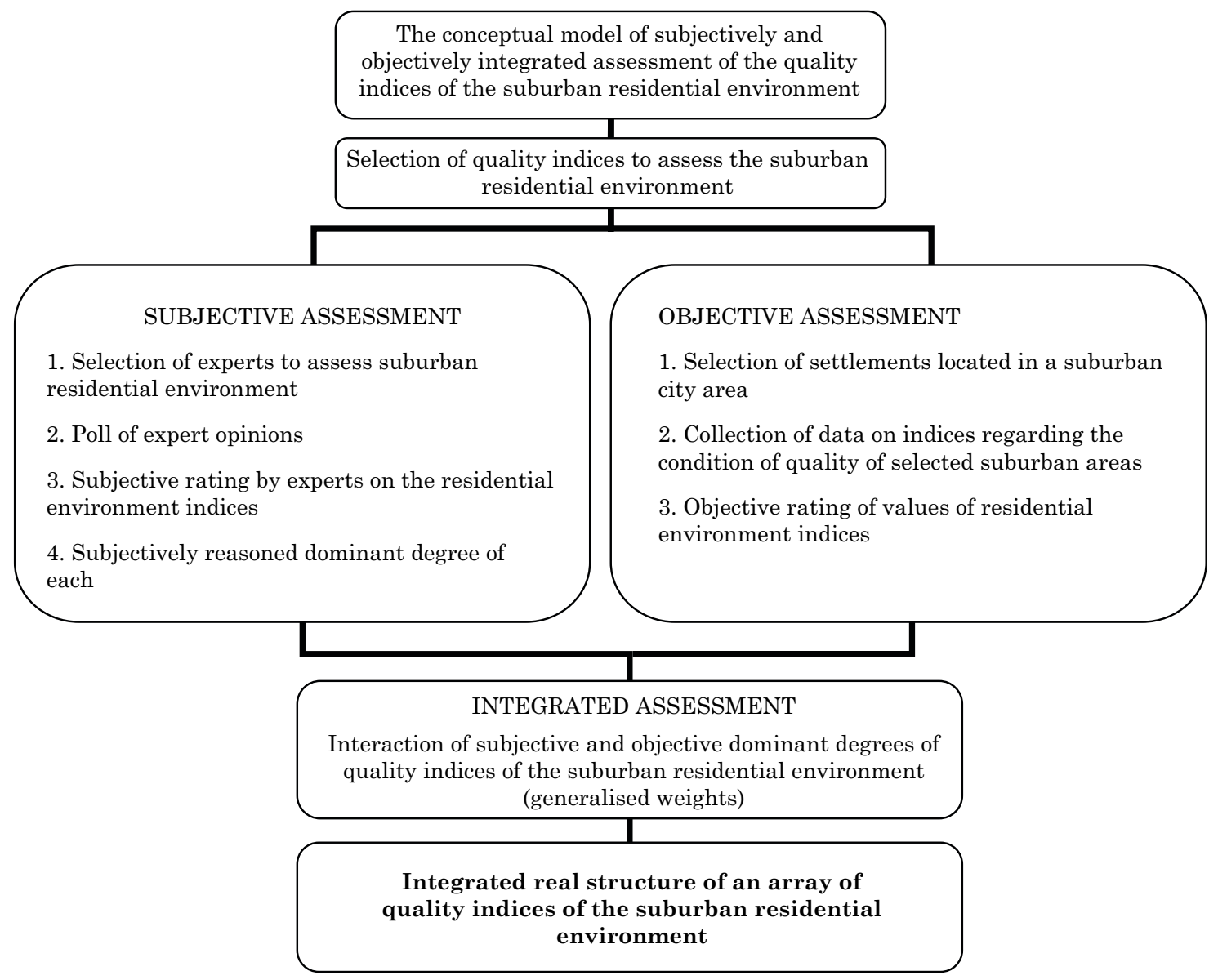

Fig. 1. The conceptual model of subjectively and objectively integrated assessment of quality indices of the suburban residential environment

The next ranking stage is to determine the significance (weights) of the applied criteria. The determined weights are subjective, objective and generalised. The entropy method evaluates the real structure of an array of data. Generalised weights of objective and subjective evaluation values of residential environment indices obtained by multi-criteria evaluation methods enable us to determine the sequence of integrally-based priority significances of the suburban residential environment indices.

These results of the conceptual model could help to compare suburban settlements by the existing conditions of the residential quality and the quality of the residential environment expected by potential residents. Such comparison of suburban settlements could be a significant tool for the control of suburban development.

\section{APPLICATION OF THE CONCEPTUAL MODEL IN CASE OF THE SUBURBAN TERRITORIES OF VILNIUS}

The Vilnius District Municipality stands out in its regional context by disproportionally vast rural residential areas of neighbouring suburbs. Dis- parities of the population in the residential areas of the district are the consequence of this territorial distribution. The comparison of the data on the population in city and district municipalities of Vilnius in the beginning of 2014 with the data of 2001 reveals a $2.3 \%$ decrease in the city and $7.4 \%$ increase in the district.

Internal migration of the population is related to the rapid growth of the housing sector and wide territorial sprawl into the suburban territories of the city. Another contributor is the accelerating conversion of gardening allotment territories into fragmented residential territories with no social, engineering or transportation infrastructure. The Vilnius City Master Plan named these internal factors the main causes of the development of the city. They are the reason behind disparities in the quality of life among zones, residential districts and individual blocks of Vilnius city. They are in conflict with the principles of sustainable development (Vilnius City Master Plan 2007). This research identified that the suburban residential environment is mostly influenced by city residents who intend to move there from their urban residential environment in the nearest. 
Vilnius suburban residential areas stand out by the increasing average number of inhabitants. The current condition of the residential environment was used for the conceptual application of the model.

\subsection{Quality indices for the assessment of the suburban residential environment}

Ten indices were selected based on the previous research (Burinskienè et al. 2013; Lazauskaitè et al. 2014), the explanation of the notion of the residential environment and the surveyed physical and functional elements, which may positively and negatively impact on the quality of the suburban residential environment. The indices were used later when evaluating the quality of the residential environment in suburbs. The selected indices include: affordability of plots of land, affordability of housing, availability of dwelling with engineering networks, development of a communication system, number of companies providing various services, density of population, commuting time, distance to the city centre, area of green planting per capita, direct investment per capita.

\subsection{Selection of experts to assess the suburban residential environment indices and the description of the poll process}

The study conducted in Vilnius in 2005 revealed that the residents of the city are capable of identifying the impact of the factors of the residential environment. Richer, more educated and younger people tend to evaluate the quality of the environment more objectively and to react more sensitively to such negative factors as air pollution, mess, high traffic volumes, etc. This group of city residents tends decide faster to move from the urban environment to a more advantageous, highquality, more personal and larger (rural) residential space. Such residents were selected as experts for the research.
Experts were selected from among urban residents who intend to relocate to the suburban residential environment in the nearest future. Therefore, experts corresponds the group of residents who are particularly concerned on creation of new suburban residential environment.

Experts had to have serious plans (should be searching for a lot or dwelling in a suburb) to move from the city to a suburban area in nearest future.

Each index of the suburban residential environment had to be evaluated, and the subjective opinion expressed by no less than 7 experts. The aim of the expert assessment was to subjectively identify the most important indices. Kendall concordance theory provides that the number of criteria must be no less than seven (Kendall 1955; Podvezko 2007). According to recommendations of researchers, the number of experts must be less than the number of indices. The degree of expert agreement depends on the number of criteria and does not depend on the number of experts (Kendall 1955; Podvezko 2007). Statistical hypotheses confirm that the concordance criteria $\chi^{2}$ have $\mathrm{m}-1$ of free degrees, where $\mathrm{m}$ is the number of indices; i.e. depends only on the number of criteria. Furthermore, it has been proved (Libby, Blashfield 1978) that in aggregate modules of estimations by experts with equal weights small expert groups are as good in the accuracy of their decisions and estimations as large expert groups (Kauko 2007).

Next, the article describes the poll process. 11 experts were asked to evaluate ten suburban residential indices using the prepared questionnaire and considering the decision to relocate from the urban residential environment to a suburban residential environment. The experts had to decide, which indices were the most significant for choosing the suburban residential environment. Each index was assessed by ranking, on

Table 1. Subjective rating by experts of the residential environment indices in 2013

\begin{tabular}{|c|c|c|c|c|c|c|c|c|c|c|c|c|}
\hline & \multicolumn{11}{|c|}{ Expert No } \\
\hline & & 1. & 2. & 3. & 4. & 5. & 6. & 7. & 8. & 9. & 10. & 11. \\
\hline No & $\begin{array}{l}\text { Quality assessment index of the residential envi- } \\
\text { ronment }\end{array}$ & \multicolumn{11}{|c|}{ Rating of indices by experts } \\
\hline 1. & Affordability of land plots & 1 & 7 & 1 & 1 & 4 & 5 & 2 & 9 & 2 & 1 & 2 \\
\hline 2. & Affordability of housing & 4 & 4 & 2 & 7 & 5 & 6 & 1 & 10 & 1 & 2 & 3 \\
\hline 3. & Availability of dwelling with engineering networks & 5 & 9 & 7 & 8 & 2 & 3 & 4 & 6 & 4 & 3 & 8 \\
\hline 4. & Development of a communication system & 2 & 3 & 6 & 2 & 3 & 1 & 5 & 8 & 5 & 5 & 1 \\
\hline 5. & Number of companies providing various services & 10 & 8 & 10 & 6 & 10 & 8 & 10 & 3 & 10 & 4 & 6 \\
\hline 6. & Density of population & 9 & 10 & 9 & 9 & 9 & 10 & 9 & 1 & 9 & 6 & 9 \\
\hline 7. & Commuting time & 6 & 5 & 3 & 5 & 1 & 4 & 8 & 7 & 8 & 7 & 5 \\
\hline 8. & Distance to the city centre & 7 & 2 & 4 & 10 & 8 & 9 & 3 & 5 & 3 & 10 & 10 \\
\hline 9. & Area of green planting per capita & 3 & 1 & 5 & 3 & 6 & 7 & 6 & 2 & 6 & 8 & 4 \\
\hline 10. & Direct investments per capita & 8 & 6 & 8 & 4 & 7 & 2 & 7 & 4 & 7 & 9 & 7 \\
\hline
\end{tabular}


the scale from 1 to 10 . Experts arranged the selected indicators in the order of priority with the greatest weight ( $1^{\text {st }}$ position) given to the most important indicator, and the lowest weight $\left(10^{\text {th }}\right.$ position) - to the least important one. This assessment by experts displayed the subjective preference of indices. Therefore, it can be used as evidence to suggest the most important quality indicators for urban residents who intend to relocate to the suburban residential environment in the nearest future.

These indicator values show the subjective conception of the quality of the suburban residential environment. They can determine the subjective decision-making when choosing a suburban settlement, according to its residential quality.

\subsection{Selection of settlements located in suburbs of Vilnius}

Four prospective residential areas of Vilnius District Municipality (Avižieniai, Didžioji Riešè, Pagiriai, Skaidiškès) were selected for the evaluation of the quality of the residential environment in the suburbs. The four residential areas will continue to be exposed to the agglomeration of Vilnius city. These residential areas are expected to experience accelerated expansion and merge with minimal territories for agriculture (Master Plan of Vilnius District 2009).

The condition of the residential environment in the residential areas was evaluated according to the principle of comparing numerical values of ten physical indices. This principle helps to measure the discrepancies in the quality of the residential environment in residential areas that formed in the same zone of impact of Vilnius city. Therefore, it is considered objective.

\section{APPLICATION OF MULTI-CRITERIA EVALUATION METHODS FOR INTEGRATED ASSESSMENT OF THE QUALITY OF SUBURBAN RESIDENTIAL ENVIRONMENT INDICES}

In the context of territorial planning, objective and subjective evaluation of the residential environment under investigation suggests the interaction of these factors. Methods of multi-criteria evaluation were used for further integral investigation of the residential environment. This investigation is conducted to meet the needs of stakeholders comprehensively and collectively.

\subsection{Agreement between expert ratings}

The rating of indices enables us to verify the agreement among expert opinions. Kendall's coefficient of concordance $W$ determines the agreement level (Kendall 1970; Podvezko 2007).

Suppose that $e_{i k}$ stands for expert rating (data from Table 1), the sum of ranks of each index is $e_{i}=\sum_{k=1}^{r} e_{i k}$, their mean value $\bar{e}=\frac{\sum_{i=1}^{m} e_{i}}{m}$ ( $i=1,2, \ldots, m ; k=1,2, \ldots, r$; here $m$ - the number of ranking criteria, $r$ - number of experts), then coefficient of concordance $W$ is calculated according to the following formula (Kendall 1970):

$$
W=\frac{12 S}{r^{2} m\left(m^{2}-1\right)} .
$$

The sum of squared deviations $S$ of ranking sums' $e_{i}$ deviations from the total mean $\bar{e}$ is calculated according to the following formula:

$$
S=\sum_{i=1}^{m}\left(e_{i}-\bar{e}\right)^{2} .
$$

Table 2. Indices of the quality of the residential environment in suburban areas of Vilnius in 2013

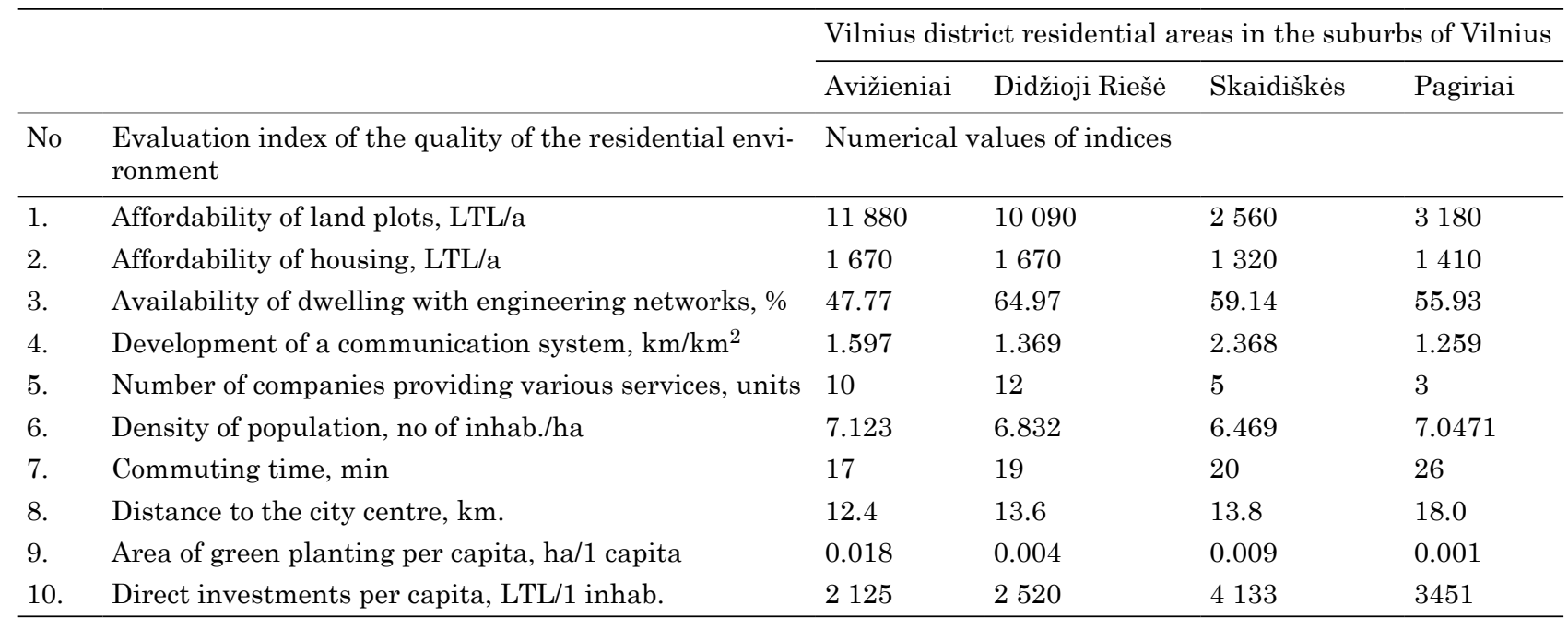


The level of expert agreement is not determined by the coefficient of concordance $W$, but by related value $\chi^{2}$, which is calculated according to the following formula (Kendall 1970):

$$
\chi^{2}=W r(m-1)=\frac{12 S}{r m(m+1)} .
$$

It has been proved (Kendall 1970) that when calculating according to the formula (3), where $\chi^{2}$ value is higher than the critical $\chi_{k r}^{2}$ value taken from $\chi^{2}$ distribution table with the freedom degree $v=m-1$ and the selected significance level $\alpha$ is close to null, then the statistical hypothesis about expert agreement of ranks is accepted.

Based on expert ranking (Table 1), the calculated coefficient of concordance is $W=0.302$. The outcome according to the formula (3) is $\chi^{2}=$ 29.936, which exceeds the critical $\chi_{k r}^{2}=16.919$ value with a significance level of $\alpha=0.05$ and the freedom degree $v=10-1=9$. It shows the agreement across expert rating.

\subsection{Determination of index significance}

The next ranking stage is to determine the significance (weights) of the applied criteria. The determined weights are subjective, objective and generalised.

The usual practice is to use subjective weights of indices determined by specialists-experts for ranks. Many methods have been developed for the determination of the weights of indices when their significance is ranked by experts (Saaty 1980, 2005; Hwang, Yoon 1981; Ustinovichius et al. 2007; Podvezko 2009; Podvezko et al. 2010; Gudienè et al. 2014; Fouladgar et al. 2012; Zavadskas et al. 2014; Aghdaie et al. 2013; Podvezko, Sivilevičius 2013; Šiožinytè, Antuchevičienè 2013; Wang et al. 2013; Tamošaitienè, Gaudutis 2013; Tamošaitienè et al. 2013; Zolfani, Šaparauskas 2013). The general idea of ranking is that the most significant criterion is attributed the highest weight, and the calculated weights are usually normalised, i.e.

$$
\sum_{i=1}^{m} \omega_{1}=1
$$

Subjective weights of criteria may be ranked by applying ranking outcomes. The most significant criterion was ranked by the least number 1 in the ranking table. Therefore, ranks $e_{i k}$ were modified according to the following formula:

$$
c_{i k}=m-1-e_{i k}
$$

and the most significant index (rank 1) was assigned the highest value, which was equal to $m$. Modified results are presented in Table 3 . The sum of modified ranks was calculated in the same manner:

$$
c_{i}=\sum_{k=1}^{r} c_{i k}
$$

and subjective weights of indices:

$$
\omega_{1}=\frac{c_{i}}{\sum_{i=1}^{m} c_{i}} .
$$

The results are presented in Table 3 .

At the moment of rating, the structure of criteria values, i.e. the real dominant degree of each index, may be evaluated additionally based on the table of physical values of indices (Table 2). These will be objective weights of indices. The entropy method is known and practically applied for such evaluation. Entropy weights are determined as follows (Hwang, Yoon 1981; Ustinovičius et al. 2007):

1. Values of indices are normalised according to the following formula:

$$
\tilde{r}_{i j}=\frac{r_{i j}}{\sum_{j=1}^{n} r_{i j}} \text {. }
$$

2. Entropy level of each index is calculated:

$$
\begin{aligned}
& E_{i}=(-1 / \ln n) \sum_{j=1}^{n} \tilde{r}_{i j} \cdot \ln \tilde{r}_{i j}, \\
& (i=1,2, \ldots, m) ; \quad 0 \leq E_{i} \leq 1 .
\end{aligned}
$$

Table 3. Modified rating table of subjective weights

\begin{tabular}{lllllllllllllll}
\hline No & 1 & 2 & 3 & 4 & 5 & 6 & 7 & 8 & 9 & 10 & 11 & $\begin{array}{l}\text { Rating sums } \\
c_{i}\end{array}$ & $\begin{array}{l}\text { Weights } \\
\omega_{i}\end{array}$ & Rating \\
\hline 1 & 10 & 4 & 10 & 10 & 7 & 6 & 9 & 2 & 9 & 10 & 9 & 86 & 0.1421 & 1 \\
2 & 7 & 7 & 9 & 4 & 6 & 5 & 10 & 1 & 10 & 9 & 8 & 76 & 0.1256 & 3 \\
3 & 6 & 2 & 4 & 3 & 9 & 8 & 7 & 5 & 7 & 8 & 3 & 62 & 0.1025 & $5-6$ \\
4 & 9 & 8 & 5 & 9 & 8 & 10 & 6 & 3 & 6 & 6 & 10 & 80 & 0.1322 & 2 \\
5 & 1 & 3 & 1 & 5 & 1 & 3 & 1 & 8 & 1 & 7 & 5 & 36 & 0.0595 & 9 \\
6 & 2 & 1 & 2 & 2 & 2 & 1 & 2 & 10 & 2 & 5 & 2 & 31 & 0.0512 & 10 \\
7 & 5 & 6 & 8 & 6 & 10 & 7 & 3 & 4 & 3 & 4 & 6 & 62 & 0.1025 & $5-6$ \\
8 & 4 & 9 & 7 & 1 & 3 & 2 & 8 & 6 & 8 & 1 & 1 & 50 & 0.0826 & 8 \\
9 & 8 & 9 & 6 & 8 & 5 & 4 & 5 & 9 & 5 & 3 & 7 & 70 & 0.1157 & 4 \\
10 & 3 & 8 & 3 & 7 & 4 & 9 & 4 & 7 & 4 & 2 & 4 & 52 & 0.0890 & 7 \\
\hline
\end{tabular}


3. The level of change of each index, i.e. nonnormalised values of entropy weights, is calculated:

$$
d_{i}=1-E_{i} \text {. }
$$

Entropy weights are normalised values of the calculated $d_{i}$ :

$$
W_{i}=\frac{d_{i}}{\sum_{i=1}^{m} d_{i}} .
$$

The entropy method evaluates the real structure of an array of data.

Entropy weights, calculated according to formulas (8)-(11), are presented in Table 4. For comparison, the table presents previously calculated subjective weights and generalized weights $q_{i}$, which were calculated according to the following formula:

$$
q_{i}=\frac{\omega_{i} W_{i}}{\sum_{i=1}^{m} W_{i}} .
$$

The comparative weights of indices enable to present the obtained results graphically (Fig. 1)

The presented graph (see Fig. 2) highlights the difference between subjective and objective weights (significance) of indices. On average, most of the subjective weights of indices are higher by three-hundredths than the objective weights of indices. Therefore, it could be assumed that only three of them (affordability of land plots; number of companies providing various services and area of green planting per capita) are less significant for experts (potential suburban residents) than when they are evaluated objectively. For example, the objective weight of an area of green planting per capita is by one-tenth higher than its subjective weight. This proportion is relevant when ranking the number of companies providing various services, where the subjective weight of this index is

Table 4. Weights of subjective, objective and generalised indices

\begin{tabular}{lllllllllll}
\hline & 1 & 2 & 3 & 4 & 5 & 6 & 7 & 8 & 9 & 10 \\
\hline $\begin{array}{l}\text { Subjective } \\
\omega_{i}\end{array}$ & 0.1421 & 0.1256 & 0.1025 & 0.1322 & 0.0595 & 0.0512 & 0.1025 & 0.0826 & 0.1157 & 0.0890 \\
\hline & 1 & 3 & $5-6$ & 2 & 9 & 10 & $5-6$ & 8 & 4 & 7 \\
\hline $\begin{array}{l}\text { Objective } \\
W_{i}\end{array}$ & 0.3523 & 0.0100 & 0.0114 & 0.0613 & 0.2351 & 0.0013 & 0.0244 & 0.0195 & 0.2224 & 0.0623 \\
\hline & 1 & 9 & 8 & 5 & 2 & 10 & 6 & 7 & 3 & 4 \\
\hline $\begin{array}{l}\text { Generalised } \\
q_{i}\end{array}$ & 0.4558 & 0.0114 & 0.0106 & 0.0738 & 0.1274 & 0.0006 & 0.0227 & 0.0147 & 0.2342 & 0.0488 \\
\hline & 1 & 8 & 9 & 4 & 3 & 10 & 6 & 7 & 2 & 5 \\
\hline
\end{tabular}

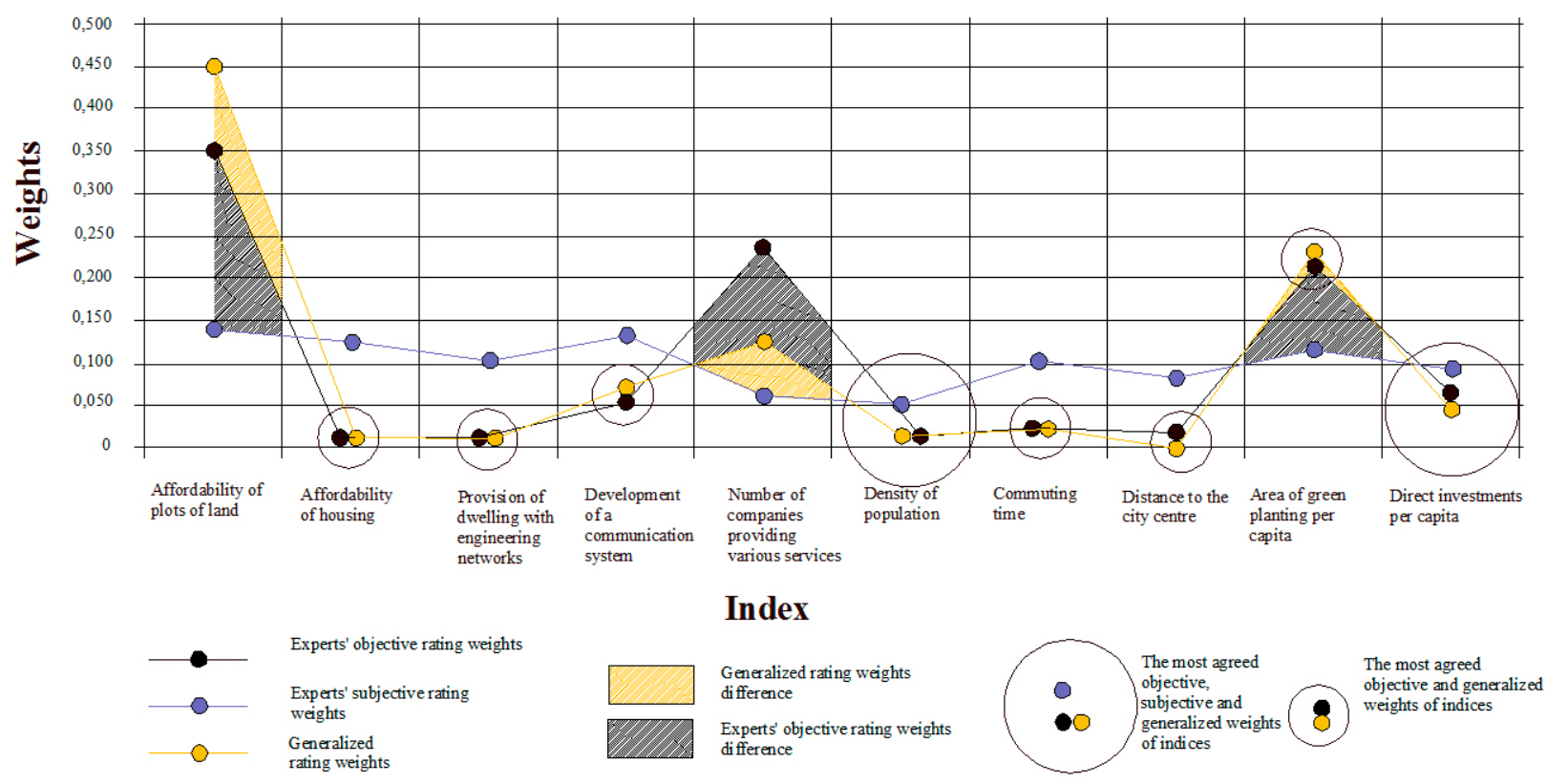

Fig. 2. Differences between comparative weights of indices 
by two tenths lower than its objective weight. The greatest difference of more than two-tenths falls to the comparison of subjective and objective weights of the index of affordability of land plots. When ranking the affordability of land plots objectively, more significance is given to it than when ranking it subjectively.

The comparison of objective weights of indices shows the higher significance of those indices, which dominate in the compared residential areas. The generalisation of the weights of indices shows that objective weights of indices are closer to the generalised ones. A majority of indices of objective and generalised weights (affordability of land plots, availability of dwelling with engineering networks, development of a communication system, population density, commuting time, distance to the city centre, direct investments per capita) differ minimally by an average of three-thousandths. The most agreed objective, subjective and generalised weights of indices are those of the population density and the direct investments per capita.

\section{AN INTEGRATED ARRAY OF THE QUALITY INDICES OF THE SUBURBAN RESIDENTIAL ENVIRONMENT}

When applying the generalised weight of an index, three indices - affordability of land plots, the number of companies providing various services and the area of green planting per capita - differed the most by the subjective and objective weights of indices, acquired a well-grounded significance. The weighted significance of these three indices enabled us to devise the following real structure particular to an array of quality indices of the residential environment:

1. Affordability of plots of land,

2. Area of green planting per capita,

3. Number of companies providing various services,

4. Development of a communication system,

5. Direct investment per capita,

6. Commuting time,

7. Distance to the city centre,

8. Affordability of housing,

9. Availability of dwelling with engineering networks,

10. Density of population.

\section{CONCLUSIONS}

1. The conceptual model of subjectively and objectively integrated assessment of quality indices of the suburban residential environment was established on the basis of scientific insights into the concept of quality of the suburban residential environment and assessment methods.

2. The conceptual model was based on the case of Vilnius. Results demonstrate the difference between used subjective and objective assessment of residential quality indicators.

3. In this research, urban residents who intended to relocate to the suburban residential environment in the nearest future were identified as residents having the most influence on the suburban residential environment.

4. Real positive indicator values of settlements are usually used by planners to characterise the residential quality of a suburban settlement and decide on the future of its development. The difference between the used subjective and objective assessment of residential quality indicators revealed that these values frequently differ from the choice of urban residents to live in such interpretive suburban residential quality.

5. Generalised weights of the objective and subjective evaluation values of the residential environment indices obtained by multicriteria evaluation methods enable us to determine the sequence of integrally-based priority significance of the residential environment indices.

6. In further research, the integrated sequence could help to compare suburban settlements by the existing conditions of residential quality and the quality of the residential environment expected by potential residents.

\section{REFERENCES}

Adriaanse, C. C. M. 2007. Measuring residential satisfaction: a residential environmental satisfaction scale (RESS), Journal of Housing and the Built Environment 22(3): 287-304. http://dx.doi.org/10.1007/ s10901-007-9082-9

Aghdaie, M. H.; Hashemkhani Zolfani, S.; Zavadskas, E. K. 2013. Decision making in machine tool selection: an integrated approach with SWARA and COPRAS-G methods, Inzinerine Ekonomika - Engineering Economics 24(1): 5-17. http://dx.doi.org/10.5755/ j01.ee.24.1.2822

Amerigo, M.; Aragones, J. I. 1997. A theoretical and methodological approach to the study of residential satisfaction, Journal of Environmental Psychology 17(1): 47-57. http://dx.doi.org/10.1006/jevp.1996.0038 
Andrews, F. M.; Withey, S. B. 1976. Social indicators of well-being: Americans' perceptions of life quality. New York: Plenum Press. http://dx.doi. org/10.1007/978-1-4684-2253-5

Beesley, K. B.; Russwurm, L. H. 1989. Social indicators and quality of life research: toward synthesis, Environments 20(1): 22-39.

Bonaiuto, M. 2004. Residential satisfaction and perceived residential environment quality, in Spielberger, C. (Ed.). Encyclopedia of applied psychology. San Diego, CA: Academic Press, 267-272. http://dx.doi. org/10.1016/B0-12-657410-3/00698-X

Bonaiuto, M.; Fornara, F.; Bonnes, M. 2006. Perceived residential environment quality in middle and lowextension Italian cities, European Review of Applied Psychology 56(1): 23-34. http://dx.doi.org/10.1016/j. erap.2005.02.011

Burinskienè, M.; Rudzkienè, V. 2007. Variability and the relationship between quality of life and real estate prices in Lithuania, International Journal of Environment and Pollution 30(3/4): 501-517. http:// dx.doi.org/10.1504/IJEP.2007.014825

Burinskienè, M.; Rudzkienè, V.; Lazauskaitė, D. 2013. The assessment of quality of life in sub peripheral urban areas in Lithuania, Social Sciences 2(6): 222230. http://dx.doi.org/10.11648/j.ss.20130206.17

Chamberlain, K. 1985. Value dimensions cultural differences and the prediction of perceived quality of life, Social Indicators Research 17(4): 345-400. http:// dx.doi.org/10.1007/BF00290321

Collis, C.; Felton, E.; Graham, P. 2010. Beyond the inner city: real and imagined places in creative place policy and practice, The Information Society: An International Journal 26(2): 104-112. http://dx.doi. org/10.1080/01972240903562738

Costello, A. B.; Osborne, J. W. 2005. Best practices in exploratory factor analysis: four recommendations for getting the most from your analysis, Practical Assessment, Research \& Evaluation 10(7). Available at: http://pareonline.net/pdf/v10n7a.pdf.

Dasgupta, P.; Weale, M. 1992. On measuring the quality of life, World Development 20(1): 119-131. http:// dx.doi.org/10.1016/0305-750X(92)90141-H

Diener, E.; Lucas, R. E. 2000. Explaining differences in societal levels of happiness: relative standards, need fulfilment, culture, and evaluation theory, Journal of Happiness Studies 1(1): 41-78. http://dx.doi. org/10.1023/A:1010076127199

Erdogan, N.; Akyol, A.; Ataman, B.; Dokmeci, V. 2007. Comparison of urban housing satisfaction in modern and traditional neighborhoods in Edirne, Turkey, Social Indicators Research 81(1): 127-148. http://dx.doi. org/10.1007/s11205-006-0018-7

Ewing, R.; Cervero R. 2010. Travel and the built environment, Journal of the American Planning Association, 76(3): 265-294. http://dx.doi. org/10.1080/01944361003766766

Fawcett, W.; Ellingham, I.; Platt, S. 2008. Reconciling the architectural preferences of architects and the public: the ordered preference model, Environment and Behaviour 40(5): 599-618. http://dx.doi. org/10.1177/0013916507304695
Felce, D. 1997. Defining and applying the concept of quality of life, Journal of Intellectual Disability Research 41: 126-135. http://dx.doi. org/10.1111/j.1365-2788.1997.tb00689.x

Figueira, J.; Greco, S.; Ehrgott, M. 2005. Multiple criteria decision analysis: state of the art survey. Springer. http://dx.doi.org/10.1007/b100605

Fornara, F.; Bonaiuto, M.; Bonnes, M. 2010. Cross-validation of abbreviated perceived residential environment quality (PREQ) and neighborhood attachment (NA) indicators, Environment and Behavior 42(2): 171196. http://dx.doi.org/10.1177/0013916508330998

Forsyth, A. 2012. Defining suburbs, Journal of Planning Literature 27(3): 270-281. http://dx.doi. org/10.1177/0885412212448101

Fouladgar, M. M.; Yazdani-Chamzini, A.; Lashggari, A.; Zavadskas, E. K.; Turskis, Z. 2012. Maintenance strategy selection using AHP and COPRAS under fuzzy environment, International Journal of Strategic Property Management 16(1): 85-104. http:// dx.doi.org/10.3846/1648715X.2012.666657

Frey, B.; Stutzer, A. 2005. Happiness research: state and prospects, Review of Social Economy 63(2): 207-228. http://dx.doi.org/10.1080/00346760500130366

Gifford, R. 2002. Environmental psychology: principles and practice. Boston: Allyn \& Bacon.

Ginevičius, R.; Podvezko, A. 2013. The evaluation of financial stability and soundness of Lithuanian banks, Ekonomska Istrazivanja - Economic Research 26(2): 191-208.

Ginevičius, R.; Podvezko, V.; Novotny, M.; Komka, A. 2012. Comprehensive quantitative evaluation of the strategic potential of an enterprise, Economic Computation and Economic Cybernetics Studies and Research 46(1): 65-84.

Gudienè, N.; Banaitis, A.; Podvezko, V.; Banaitienè, N. 2014. Identification and evaluation of the critical success factors for construction projects in Lithuania: AHP approach, Journal of Civil Engineering and Management 20(3): 350-359. http://dx.doi.org/ 10.3846/13923730.2014.914082

Helburn, N. 1982. Geography and the quality of life, Annals of the Association of American Geographers 72(4): 445-456. http://dx.doi.org/10.1111/j.1467-8306.1982. tb01837.x

Hwang, C. L.; Lin, M. J. 1987. Group decision making under multiple criteria: methods and applications. Springer Verlag. http://dx.doi.org/10.1007/978-3-64261580-1

Hwang, C. L.; Yoon, K. 1981. Multiple attribute decision making-methods and applications. A state of the art survey. Berlin, Heidelberg, New York: Springer-Verlag. http://dx.doi.org/10.1007/978-3-642-48318-9

James, R. N. 2008. Residential satisfaction of elderly tenants in apartment housing, Social Indicators Research 89(3): 421-437. http://dx.doi.org/10.1007/ s11205-008-9241-8

Johnson, D. L.; Ambrose, S. H.; Bassett, T. J.; Bowen, M. L.; Crummey, D. E.; Isaacson, J. S.; Johnson, D. N.; Lamb, P.; Saul, M.; Winter-Nelson, A. E. 1997. Meanings of environmental terms, Jour- 
nal of Environmental Quality 26: 581-589. http:// dx.doi.org/10.2134/jeq1997.00472425002600030002x

Juškevičius, P.; Burinskienè, M. 2007. Quality factors of the residential environment in urban planning, International Journal of Environmental and Pollution 30(3-4): 471-484. http://dx.doi.org/10.1504/ IJEP.2007.014823

Kaklauskas, A.; Zavadskas, E. K. 2009. Theories of investment in property: use of information, knowledge and intelligent technologies, in Ruddock, L. (Ed.). Economics for the Modern Built Environment. Taylor \& Francis, 249-268.

Kauko, T. 2007. An analysis of housing location attributes in the inner city of Budapest, Hungary, using expert judgements, International Journal of Strategic Property Management 11(4): 209-225. http:// dx.doi.org/10.1080/1648715X.2007.9637570

Kendall, M. 1955. Rank correlation methods. Hafner Publishing House. N.Y.

Kendall, M. 1970. Rank correlation methods. London: Griffin.

Kline, R. B. 2005. Principles and practice of structural equation modelling. $2^{\text {nd }}$ ed. New York: Guilford Press.

Lansing, J. B.; Marans, R. W. 1969. Evaluation of neighborhood quality, Journal of the American Institute of Planners 35(3): 195-199. http://dx.doi. org/10.1080/01944366908977953

Lawrence, D. L.; Low, S. M. 1990. The built environment and spatial form, Annual Review of Anthropology 19: 453-505. http://dx.doi.org/10.1146/annurev. an.19.100190.002321

Lazauskaitè, D.; Griškevičiūtè-Gečienè, A.; Šarkienė, E.; Zinkevičienè, V. 2014. Quality analysis of Vilnius city suburban spatial development, in $9^{\text {th }}$ International Conference Environmental Engineering, 22-23 May 2014, Vilnius: Technika, 1-9.

Libby, R.; Blashfield, R. K. 1978. Performance of a composite as a function of the number of judges, Organizational Behaviour and Human Performance 21(2): 121-129. http://dx.doi.org/10.1016/00305073(78)90044-2

Marans, R. W. 2003. Understanding environmental quality through quality of life studies: the 2001 DAS and its use of subjective and objective indicators, Landscape and Urban Planning 65(1-2): 73-83. http://dx.doi.org/10.1016/S0169-2046(02)00239-6

Marans, R. W.; Couper, M. 2000. Measuring the quality of community life: a program for longitudinal and comparative international research, in Proceedings of the Second International Conference on Quality of Life in Cities, vol. 2. Singapore.

Modarres, A.; Kirby, A. 2010. The suburban question: notes for a research program, Cities 27: 114-121. http://dx.doi.org/10.1016/j.cities.2009.11.009

Moffat, S.; Kohler, N. 2008. Conceptualizing the built environment as a social-ecological system, Building Research \& Information 36(3): 248-268. http://dx.doi. org/10.1080/09613210801928131

Olsen, M. E.; Merwin, D. J. 1977. Towards a methodology for conducting social impacts assessment by using quality of social life indicators, in Finsterbuch and Wolf (1987), op cit., 43-63.
Phelps, N. A. 2010. Suburbs for nations? Some interdisciplinary connections on the suburban economy, Cities 27: 68-76. http://dx.doi.org/10.1016/j.cities. 2009.11.005

Perlavičiūtè, G.; Steg, L. 2012. Quality of life in residential environments, Psyecology 3(3): 325-340. http:// dx.doi.org/10.1174/217119712802845732

Podvezko, V. 2009. Application of AHP technique, Journal of Business Economics and Management 10(2): 181-189. http://dx.doi.org/10.3846/16111699.2009.10.181-189

Podvezko, V. 2007. Determining the level of agreement of expert estimates, International Journal of Management and Decision Making 8(5/6): 586-600. http:// dx.doi.org/10.1504/IJMDM.2007.013420

Podvezko, V. 2011. The Comparative analysis of MCDA methods SAW and COPRAS, Inzinerine EkonomikaEngineering Economics 22(2): 134-146. http://dx.doi. org/10.5755/j01.ee.22.2.310

Podvezko, V.; Mitkus, S.; Trinkūnienè, E. 2010. Complex evaluation of contracts for construction, Journal of Civil Engineering and Management 16(2): 287-297. http://dx.doi.org/10.3846/jcem.2010.33

Podvezko, V.; Podvezko, A. 2010. Dependence of multi-criteria evaluation result on choice of preference functions and their parameters, Technological and Economic Development of Economy 16(1): 143-158. http://dx.doi.org/10.3846/tede.2010.09

Podvezko, V.; Sivilevičius, H. 2013. The use of AHP and rank correlation methods for determining the significance of the interaction between the elements of a transport system having a strong influence on traffic safety, Transport 28(4): 389-403. http://dx.doi.org/10. 3846/16484142.2013.866980

Prutkin, J.; Feinstein, A. 2002. Quality-of-life measurements: origin and pathogenesis, Yale Journal of Biology and Medicine 75: 79-93.

Rapoport, A. 1976. The mutual interaction of people and their built environment: a cross-cultural perspective. Chicago: Aldine. http://dx.doi.org/10.1515/9783110819052

Saaty, T. L. 2005. The analytic hierarchy and analytic network processes for the measurement of intangible criteria and for decision-making, in Figueira, J.; Greco, S.; Ehrgott, M. (Eds.). Multiple criteria decision analysis: state of the art surveys, Chapter 9. Springer, 345-408. http://dx.doi.org/10.1007/0-38723081-5_9

Saaty, T. L. 1980. The analytic hierarchy process. New York: M. Graw-Hill.

Šiožinytè, E.; Antuchevičienè, J. 2013. Solving the problems of daylighting and tradition continuity in a reconstructed vernacular building, Journal of Civil Engineering and Management 19(6): 873-882. http:// dx.doi.org/10.3846/13923730.2013.851113

Steg, L.; De Groot, J.; Forward, S.; Kaufmann, C.; Risser, R .; Schmeidler, K.; Martinsigh, L.; Urbani, L. 2007. Assessing life quality in transport planning and urban design: definition, operationalization, assessment and implementation, in Marshall, S.; Banister, D. (Eds.). Land use and transport: European research towards integrated policies, Chapter 10. Amsterdam: Elsevier. http://dx.doi.org/10.5379/ urbaniizziv-en-2006-17-01-02-004 
Tamošaitienè, J.; Gaudutis, E. 2013. Complex assessment of structural systems used for high-rise buildings, Journal of Civil Engineering and Management 19(2): 305-317. http://dx.doi.org/10.3846/13923730. 2013.772071

Tamošaitienè, J.; Šipalis, J.; Banaitis, A.; Gaudutis, E. 2013. Complex model for the assessment of the location of high-rise buildings in the city urban structure, International Journal of Strategic Property Management 17(1): 93-109. http://dx.doi.org/10.3846/ $1648715 x .2013 .781968$

The General plan of Vilnius District. 2009. 13-15. Available at: http://teritorijuplanavimas.vrsa.lt/go.php/ Bendrasis-planas911692399861

The Vilnius city General Plan. 2007. 48-59. Available at: http://old.vilnius.lt/bplanas/index. php? mid=50\&lang=lt

Tupėnaitė, L.; Zavadskas, E. K.; Kaklauskas, A.; Turskis, Z.; Seniut, M. 2010. Multiple criteria assessment of the built and human environment renovation alternatives, Journal of Civil Engineering and Management 16(2): 257-266. http://dx.doi.org/10.3846/ jcem.2010.30

Ustinovichius, L.; Zavadskas, E. K.; Podvezko, V. 2007. Application of a quantitative multiple criteria decision making (MCDM-1) approach to the analysis of investments in construction, Control and Cybernetics 36(1): 251-268.

Wang, W. C.; Yu, W.; Yang I. T.; Lin, C. C.; Lee, M. T.; Cheng, Y. Y. 2013. Applying the AHP to support the best-value contractor selection - lessons learned from two case studies in Taiwan, Journal of Civil Engineering and Management 19(1): 24-36. http:// dx.doi.org/10.3846/13923730.2012.734851

Van Kamp, I.; Leidelmeijer, K.; Marsman, G.; De Hollander, A. 2003. Urban environmental quality and human well-being. Towards a conceptual framework and demarcation of concepts: a literature study, Landscape and Urban Planning 65: 5-18. http:// dx.doi.org/10.1016/s0169-2046(02)00232-3

Van Poll, R. 1997. The perceived quality of the urban residential environment: a multi-attribute evaluation. Doctoral dissertation. University of Groningen.

Vera-Toscano, E.; Alteca-Amestoy, V. 2008. The relevance of social interactions on housing satisfaction, Social Indicators Research 86: 257-274. http://dx.doi. org/10.1007/s11205-007-9107-5

Yazdani-Chamzini, A. 2014. An integrated fuzzy multi criteria group decision making model for handling equipment selection, Journal of Civil Engineering and Management 20(5): 660-673. http://dx.doi.org/ 10.3846/13923730.2013.802714

Zavadskas, E. K.; Turskis, Z.; Kildienè, S. 2014. State of art surveys of overviews on MCDM/MADM methods, Technological and Economic Development of Economy 20(1): 165-179. http://dx.doi.org/10.3846/202949 13.2014.892037

Zolfani, S. H.; Šaparauskas, J. 2013. New application of SWARA method in prioritizing sustainability assessment indicators of energy system, Inzinerine Ekonomika-Engineering Economics 24(5): 408-414. http:// dx.doi.org/10.5755/j01.ee.24.5.4526 